\title{
Analysis of altered gene expression specific to embryotoxic chemical treatment during embryonic stem cell differentiation into myocardiac and neural cells
}

\author{
Noriyuki Suzuki, Satoshi Ando, Kayo Sumida, Nobuyuki Horie and Koichi Saito \\ Environmental Health Science Laboratory, Sumitomo Chemical Co., Ltd., 3-1-98 Kasugadenaka, Konohana-Ku, \\ Osaka 554-8558, Japan
}

(Received April 21, 2011; Accepted July 29, 2011)

\begin{abstract}
Embryonic stem cells (ES cells), pluripotent cells derived from the inner cell mass of blastocysts, differentiate in vitro into a variety of cell types representing all three germ layers. They therefore constitute one of the most promising in vitro tools for developmental toxicology. To assess the developmental toxicity of chemicals using ES cells easily, identification of effective marker genes is a high priority. We report here altered gene expression during ES cell differentiation into myocardiac and neural cells on treatment with some embryotoxic and non-embryotoxic chemicals. Decreases in several undifferentiated markers such as Oct3/4 and Nanog, and elevated expression of genes associated with heart development or the central nervous system, respectively, were found on microarray analysis. Under differentiation of ES cells into myocardic cells, 107 genes were substantially up-regulated. Decrease in the expression of 13 genes of these (Hand1, Pim2, Tbx20, Myl4, Myl7, Hbb-bh1, Hba-a1, Col1a2, Hba-x, Cmya1, Pitx2, Smyd1 and Adam19) was observed specifically by embryotoxic chemicals. Of the 107 genes up-regulated under differentiation into neurons, 22 genes (Map2, Cpe, Marcks, Ptbp2, Sox11, Tubb2b, Vim, Arx, Emx2, Pax6, Basp1, Ddr1, Ndn, Sfrp, Ttc3, Ubqln2, Six3, Dcx, L1cam, Reln, Wnt1 and Nnat) showed reduced expression specifically by embryotoxic chemicals. Almost all gene sets identified in this study are known to be indispensable for differentiation and development of heart and brain tissues, and thus may serve in early detection or prediction of embryotoxicity of chemicals in vitro.
\end{abstract}

Key words: Embryonic stem cells, Developmental toxicity, Embryotoxicity, Myocardiac cell, Neural cell

\section{INTRODUCTION}

Developmental toxicity is one of the most serious side effects of chemical compounds and evaluation of adverse effects on reproduction and embryonic development is therefore an important objective of toxicological safety assessment. Because with in vivo reproductive toxicity the influence of chemicals in processes of embryogenesis must be taken into consideration, it is difficult to predict using transformed cell lines. While usage of primary cells, cultures of dissociated cells from rat embryo limb buds or whole embryos from rat for alternative methods have been evaluated (Spielmann, 1998), it has been argued that these tests are unlikely to gain widespread acceptance (Bremer and Hartung, 2004). Moreover, it is generally acknowledged that the existing in vivo assays for developmental toxicity are very time consuming, laborious, expensive and conflicting with the current need for rapid screening of potential drugs and chemicals. There is an increasing political and public demand for reduction in the use of laboratory animals.

Therefore, the development of alternative screening procedures is a high priority. To reduce the amount of animal experimentation, several in vitro systems have recently been developed using primary cells, cultures of dissociated cells from rat embryo limb buds (micromass test, MM test) (Flint and Orton, 1984) or whole embryos from Xenopus, the chicken or the rat (whole embryo culture, WEC) (Schmid et al., 1985). However, these tests are unlikely to gain widespread acceptance and use (Bremer and Hartung, 2004).

Embryonic stem cells (ES cells) are pluripotent cells

Correspondence: Noriyuki Suzuki (E-mail: suzukin7@sc.sumitomo-chem.co.jp) 
derived from inner cell mass of blastocysts which are known to differentiate in vitro into a wide variety of cell types representing all three germ layers (Evans and Kaufman, 1981). Under appropriate culture conditions some of them differentiates spontaneously into contracting myocardial cells (Scholz et al., 1999). Moreover, various kinds of neurons such as the dopaminergic and the telencephalic precursor neurons can be induced efficiently by appropriate methods (Kawasaki et al., 2000, Watanabe et al., 2005). Many studies have focused on ES cell differentiation as a model for studying developmental biology while others have taken advantage of these remarkable cells as potential tools for drug or chemical embryotoxicity screening (Rohwedel et al., 2001; Davila et al., 2004). In the 1990s, several groups used ES cells to establish an in vitro developmental toxicity test, called the "Embryonic stem cell test (EST)“ (Spielmann et al., 1997). The EST was designed to predict embryotoxicity based on the inhibition of differentiation of ES cells into contracting myocardiac cells in combination with cytotoxicity data for ES and 3T3 cells. This method has been validated by the European Centre for the Validation of Alternative Methods (ECVAM) as being reliable for the prediction of embryotoxicity in vivo (Genschow et al., 2004). Using more than 20 reference compounds with different embryotoxic potencies (non-embryotoxic, weakly and strongly embryotoxic), the EST was shown to provide a correct judgment in $78 \%$ of all experiments. Remarkably, a predictivity of $100 \%$ was obtained for strong embryotoxicants. However, a major weakness of the EST is its reliance on a morphological endpoint (contracting myocardiac cells) and the need for experienced personnel ensuring its reliable assessment. In addition, the assay time of 10 days is rather too long for screening purposes for drugs and chemicals. Myocardiac cells were originally selected as target cells due to the very easy identification of contracting cells in bulk cultures of differentiating embryonic stem cells and due to the fact that the heart is the first organ which develops during organogenesis. However, additional major target tissues of teratogens such as the nerve system and skeletal system have to be included in order to obtain precise information about the teratogenic potential of chemicals (Bremer and Hartung, 2004). Therefore identification of critical endpoints for the early detection and prediction of embryotoxicity in major target tissues of teratogens is needed for development of convenient and accurate in vitro alternative tests for developmental toxicity.

The aim of the present study was to estimate alteration in the expression of genes related to developmental toxicity specific to embryotoxic chemicals during ES cell differentiation into myocardiac and neural cells. DNA microarray analysis was applied to determine upand down-regulated genes with 6 embryotoxic and 6 nonembryotoxic chemicals, several genes being identified as specifically altered by embryotoxic chemicals.

\section{MATERIALS AND METHODS}

\section{Test chemicals}

Twelve test chemicals (Table 1) used in the ECVAM international validation study (Brown, 2002; Genschow et al., 2004) were purchased from Sigma-Aldrich (St. Louis, MO, USA). The chemicals were dissolved in appropriate solvents, that is, phosphate-buffered saline (PBS), dimethyl sulfoxide (DMSO), or ethanol (EtOH) as indicated.

Table 1. List of selected test chemicals and the concentration for treatment

\begin{tabular}{|c|c|c|c|c|}
\hline In vivo category & Chemicals & $\begin{array}{l}\text { Myocardiac cell } \\
\text { dose }(\mu \mathrm{g} / \mathrm{ml})\end{array}$ & $\begin{array}{c}\text { Neural cell } \\
\text { dose }(\mu \mathrm{g} / \mathrm{ml})\end{array}$ & Solvent \\
\hline \multirow[t]{6}{*}{ Strong-embryotoxic } & 5-Fluorouracil & 0.05 & 0.04 & PBS \\
\hline & Hydroxyurea & 4 & 4 & PBS \\
\hline & 6-Amino nicotinamide & 1 & 1.5 & DMSO \\
\hline & 5-Bromo-2'-deoxyuridine & 1.5 & 0.5 & PBS \\
\hline & Methotrexate & 0.6 & 0.2 & PBS \\
\hline & all-trans-Retinoic acid & 0.001 & 0.001 & DMSO \\
\hline \multirow[t]{6}{*}{ Non-embryotoxic } & Saccharin sodium salt hydrate & 1000 & 1000 & PBS \\
\hline & Ascorbic acid & 20 & 20 & PBS \\
\hline & Isoniazide & 125 & 150 & PBS \\
\hline & $(+)$-Camphor & 1000 & 1000 & $\mathrm{EtOH}$ \\
\hline & Acrylamide & 25 & 25 & DMSO \\
\hline & PenicillinG & 1000 & 1000 & PBS \\
\hline
\end{tabular}

*Teratogenicity of test chemicals are summarized in previous reports (Smith et al., 1983; Brown, 2002). 
Genes related to developmental toxicity

\section{Cell lines and culture conditions}

Mouse ES cells, line D3, purchased from American Type Culture Collection (ATCC) were cultured in high glucose (4.5 g glucose/1) Dulbecco's modified Eagle's medium (DMEM; Invitrogen, Carlsbad, CA, USA) containing 15\% fetal calf serum (Hyclone, South Logan, UT, USA), 2 mM glutamine (Invitrogen), antibiotics (50 U/ml penicillin and $50 \mu \mathrm{g} / \mathrm{ml}$ streptomycin; Nacalai tesque, Kyoto, Japan), 1\% non-essential amino acids (Invitrogen), $0.1 \mathrm{mM}$ 2-mercaptoethanol (Sigma-Aldrich) and 1,000 $\mathrm{U} / \mathrm{ml}$ murine leukemia inhibitory factor (mLIF; Millipore, Japan), as described previously (Spielmann et al., 1997). Cells maintained in $60-\mathrm{mm}^{2}$ cell culture dishes (BD Falcon, Tokyo, Japan) under 5\% $\mathrm{CO}_{2}$ and $95 \%$ humidity at $37^{\circ} \mathrm{C}$ were routinely passaged every $2-3$ days.

\section{Differentiation of ES cells into myocardiac cells}

Differentiation of mouse ES cells into myocardiac cells was carried out under the EST protocol as described previously (Spielmann et al., 1997; Seiler et al., 2006). Briefly, 750 cells in $20 \mu \mathrm{l}$ differentiation medium (as described under cell lines and culture conditions but without mLIF to allow differentiation) were placed on the lid of a petri dish filled with phosphate buffered saline (PBS, Invitrogen) and then incubated for 3 days at $37^{\circ} \mathrm{C}$ under $5 \% \mathrm{CO}_{2}$ and $95 \%$ humidity ("hanging drop" culture). During this period the cells formed aggregates referred to as embryoid bodies (EBs). After 3 days of "hanging drop" culture the EBs were transferred to bacterial petri dishes for another 2 days. On day 5, EBs were plated separately into wells of a 24-multiwell tissue culture plate (BD Falcon) to allow adherence and outgrowth and development of spontaneously contracting cardiac muscle cells. Differentiation was determined by contracting of myocardiac cells under microscopic inspection at day 10 .

\section{Differentiation of ES cells into neural cells}

Differentiation of mouse ES cells into neural cells was carried out under serum-free conditions as described previously (Watanabe et al., 2005). Differentiation medium was prepared as follows: G-MEM supplemented with 5\% Knockout serum replacement (KSR) (Invitrogen), $2 \mathrm{mM}$ glutamine, $1 \mathrm{mM}$ pyruvate (Invitrogen), $0.1 \mathrm{mM}$ nonessential amino acids, and $0.1 \mathrm{mM} 2$-mercaptoethanol. ES cells were dissociated with $0.25 \%$ trypsin-EDTA to single cells and aliquots $\left(5 \times 10^{4}\right.$ cells $/ \mathrm{ml}$ differentiation medium) were seeded into $10 \mathrm{ml}$ of differentiation medium in bacterial-grade dishes to generate floating cell aggregates spontaneously. Then, cell aggregates were replaced on differentiation medium in 24-multiwell tissue culture plates coated with poly-D-lysine, raminine and fibronec- tin, at a density of 50 aggregates per well on day 5 . Differentiation was determined by counting neurofilaments with microscopic inspection of differentiated cells labeled with Vybrant ${ }^{\circledR}$ DiI cell-labeling solution (LONZA, Tokyo, Japan) at day 10.

\section{Determination of the genes involved in ES cell differentiation into myocardiac and neural cells}

In order to analyze global changes in gene expression during ES cell differentiation into myocardiac and neural cells, gene expression was assessed by DNA microarray at 6 different time points (days 0, 2, 4, 6, 8 and 10). Three samples of mixtures of $40 \mathrm{EBs}$ or 50 floating aggregates, respectively, were collected on days $0,2,4,6,8$ and 10 of cardiac and neural cell differentiation. Total RNA was extracted using TRIzol solvent (Invitrogen) for gene expression analysis with the GeneChip system (Affymetrix, Japan) following the manufacturer's protocol. Briefly, double-strand DNA was synthesized from $3 \mu \mathrm{g}$ of total RNA and the obtained cDNAs were used as templates for in vitro transcription. Fragmented in vitro transcripts were hybridized overnight onto Mouse Genome 4302.0 microarrays (Affymetrix), stained, washed and scanned with an Affymetrix GeneArray scanner. The obtained image files were analyzed with the Affymetrix data suite system.

To determine the genes involved in myocardiac and neural cell differentiation, significant alterations (more than 2-fold) in the obtained expression data were extracted by statistical analysis (ANOVA) of gene expression differences between day 0 and the other days. Then, genes which were substantially up-regulated during the differentiation processes were extracted on the basis of change in signal value of gene expression (a more than 1,000 signal value).

\section{Treatment with embryotoxic and non-embryotoxic chemicals during ES cell differentiation into myocardiac and neural cells}

Differentiation of mouse ES cells into myocardiac or neural cells with test chemicals was performed basically as described above. The cells were treated with test compounds on days 0,3 and 5 with medium changes and differentiated cells were collected periodically from days 1 to 10 . Total RNAs of all samples were extracted with TRIzol reagent. The dose levels of the test compounds were set on the basis of the maximum non-effect concentration in cytotoxicity assays or the minimum concentration for $100 \%$ inhibition in differentiation assays (Table 1). Cytotoxicity assays of test chemicals were performed as previously described (Scholz et al., 1999) with minor modification. Briefly, 500 ES cells were seeded into a 
96-multiwell tissue culture plate in differentiation medium with or without test chemicals. Medium was changed on days 3 and 5. Cytotoxicity was measured on day 10 using the CellTiter-Glo ${ }^{\circledR}$ Luminescent Cell Viability Assay (Promega, Japan) based on the MTT assay, according to the manufacturer's instructions. Differentiation assays were performed basically as described above. The cells were treated with test compounds on days 0,3 and 5 with medium changes and percentage inhibition of differentiation into myocardiac or neural cells was calculated by counting the numbers of contracting EBs or neurofilaments, respectively.

\section{Analysis of genes featuring altered expression on treatment with embryotoxic and non-embryotoxic chemicals during ES cell differentiation into myocardiac and neural cells}

To confirm the expression levels of the genes extracted in the DNA microarray analysis described above, quantitative PCR was used. Reverse transcription was performed with SuperScript III for $50 \mathrm{~min}$ at $42^{\circ} \mathrm{C}$, and oligo (dT) as a primer, using $300 \mathrm{ng}$ of total RNA. The mRNA was quantified with TaqMan gene expression assays (Applied Biosystems, Japan) on a 7900 Fast Real-Time PCR System, with a two-step PCR procedure according to manufacturer's protocol. The thermal cycling conditions were: $95^{\circ} \mathrm{C}$ for $20 \mathrm{sec}$ for the first cycle, followed by 40 cycles of $95^{\circ} \mathrm{C}$ for $3 \mathrm{sec}$ and $60^{\circ} \mathrm{C}$ for $20 \mathrm{sec}$. The TaqMan probes used in the present study are shown in Tables 2 to 5 .

To estimate the genes involved in embryotoxicity, RNA samples from differentiated myocardiac or neural cells treated with the embryotoxicants and non-embryotoxicants described above were analyzed by quantitative PCR at the time points with the highest expression of each gene.

\section{RESULTS}

\section{Determination of genes involved in ES cell dif- ferentiation into myocardiac cells}

Global changes in the gene expression during ES cell differentiation into myocardiac cells were analyzed by DNA microarray at 6 different time points (days 0,2 , 4, 6, 8 and 10). As shown in Table 2a, changes in gene expression of typical marker genes for an undifferentiated state (Oct3/4 and Nanog) decreased gradually during the cardiac differentiation. In addition, expression of 25 well-known mesoderm markers and several genes playing important roles in vertebrate heart formation (list in Table $2 b$ ) were analyzed. In the early differentiation stage (days 0 to 4), expression of Bmp2, Cer1, Nodal and T (brachyury) was elevated, and increases in the expression of Gata4, Nkx2-5, Mef2a, Mef2c, Cdh2, Hand1, Hand2, Pitx2, Xin, Smyd1, Tbx20, Tbx5, Adam19, Tpm2, Myh6, Col1a2, Myl4, Myl7, Hbb-bh1, Hba-a1 and Hba-x were found in the middle and late differentiation stages (days 6 to 10 ) (Table 2b). These expression patterns demonstrated a rough concordance with those observed during differentiation in early embryogenesis in vivo (Guan et al., 1999; Rohwedel et al., 2001). Examples with more than 2-fold significant change were extracted by comparative analysis between day 0 and other days using the obtained expression data from microarray analysis. The genes substantially up-regulated more than 1,000 signal values were identifiedas candidate genes involved in ES cells differentiation into myocardiac cells. Totals of 21, 39, 26, 65, and 10 were identifiedin days $2,4,6,8$ and 10 , respectively, 82 genes being obtained without overlapping for further analysis (Table 3).

\section{Determination of genes involved in ES cell differentiation into neural cells}

As shown in Table $4 a$, the expression of Oct $3 / 4$ and Nanog decreased gradually during neural differentiation. In contrast, the expression levels of a neural progenitor marker, Nest (Nestin) (Kawaguchi et al., 2001), was only increased in the middle differentiation stage (day 4 to 6 ). In the late differentiation stage, increases in 22 gene expressions of ectoderm markers, neurotransmitters, and several genes playing important roles in brain development were observed (Table 4b). These expression patterns roughly also reflected the gene expression patterns observed during the differentiation of early embryogenesis in vivo (Guan et al., 1999; Rohwedel et al., 2001). The genes substantially up-regulated more than 1,000 signal values in DNA microarray analysis were identifiedas candidate genes involved in ES cell differentiation into neural cells. Totals of $34,44,37,33$ and 53 were identifiedin days $2,4,6,8$ and 10 , respectively, 85 genes being obtained without overlapping for further analysis (Table 5).

\section{Analysis of genes with altered expression by treatment with embryotoxic and non-embryotoxic chemicals during ES cell differentiation into myocardiac and neural cells}

To estimate genes related to developmental toxicity, six embryotoxicants (5-fluorouracil, hydroxyurea, 6-aminonicotinamide, 5-bromo-2'-deoxyuridine, methotrexate and all-trans retinoic acid) and six non-embryotoxicants (penicillin G, saccharin sodium salt hydrate, ascorbic 
Genes related to developmental toxicity

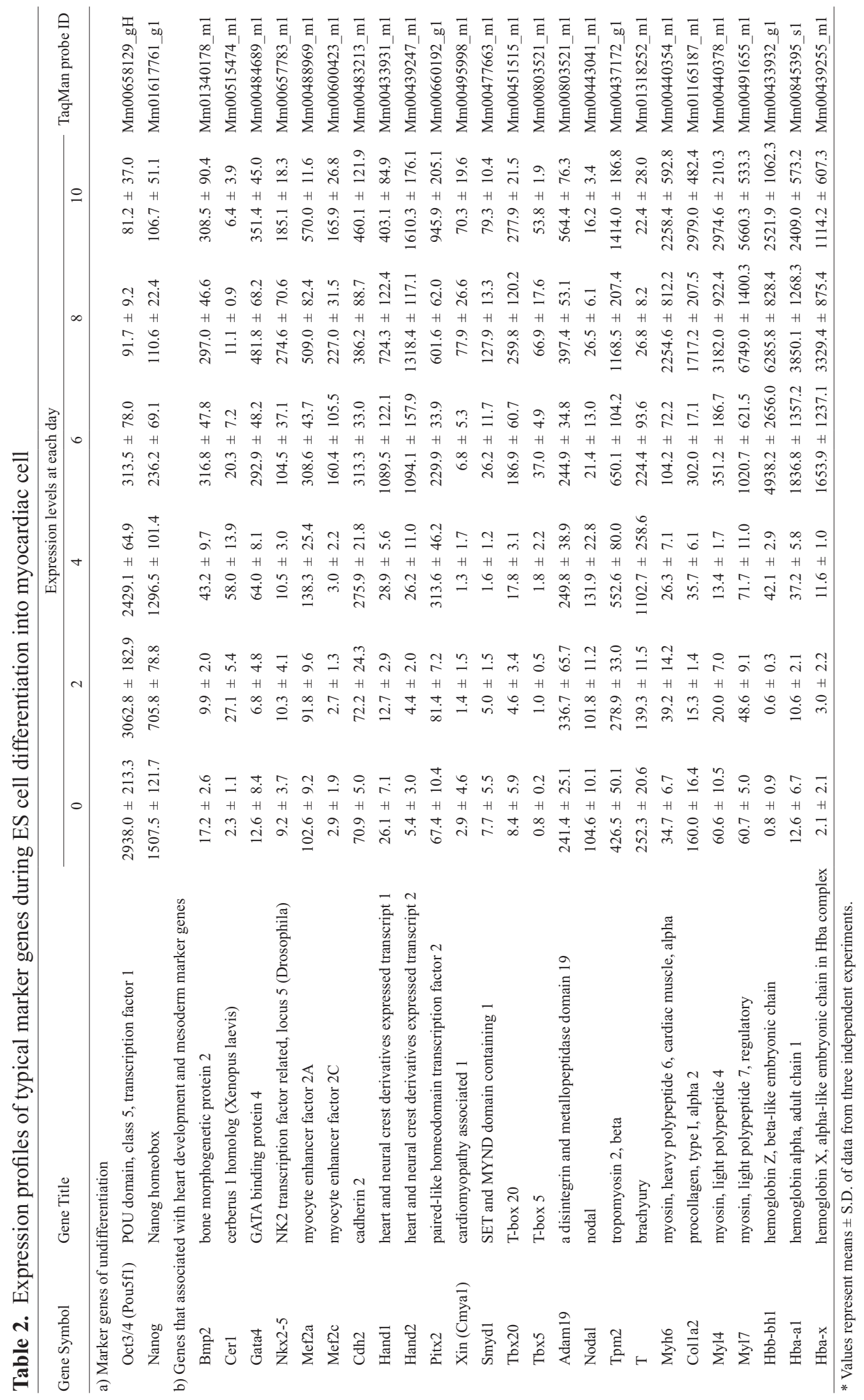

Vol. 36 No. 5 
N. Suzuki et al.

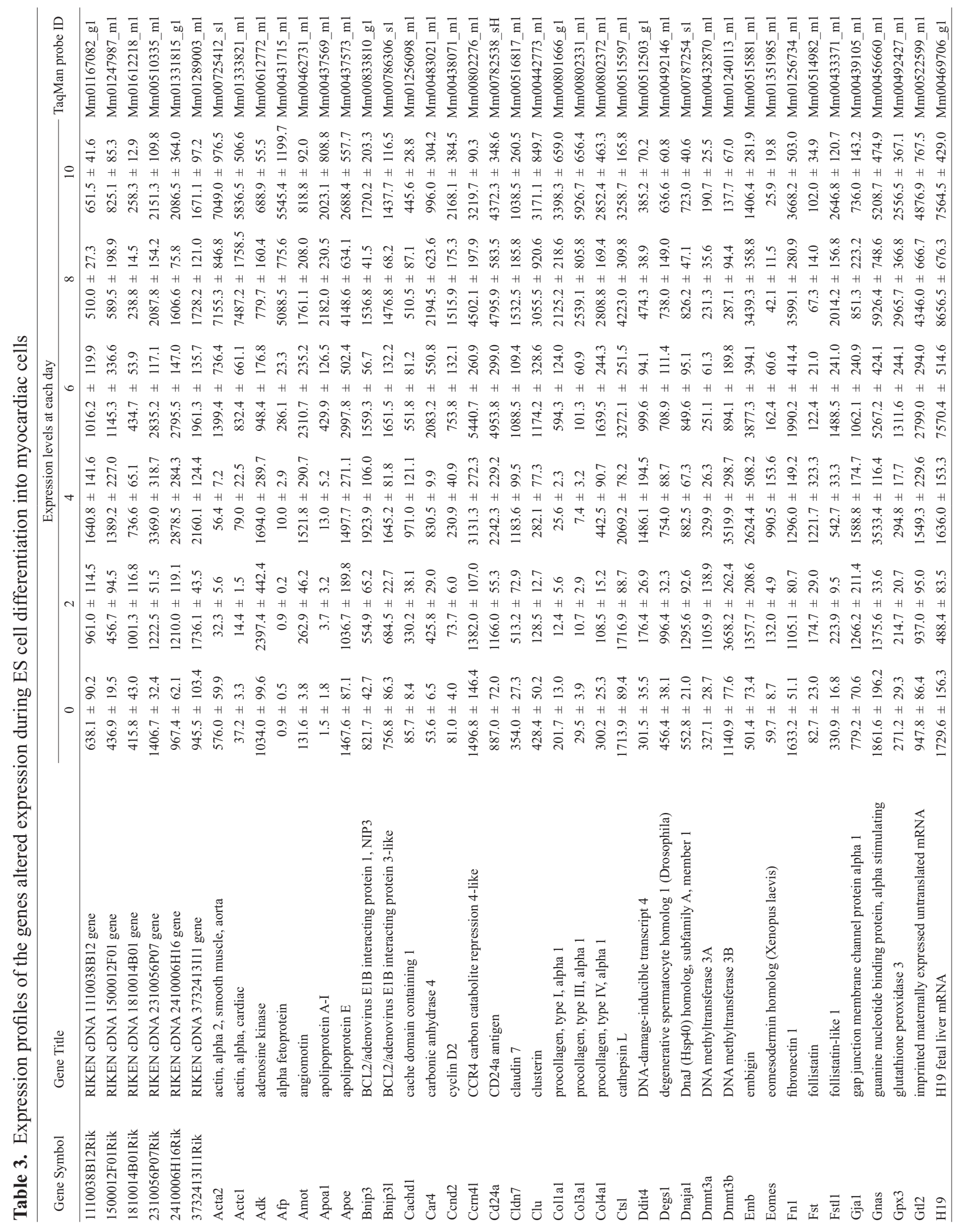

Vol. 36 No. 5 
Genes related to developmental toxicity

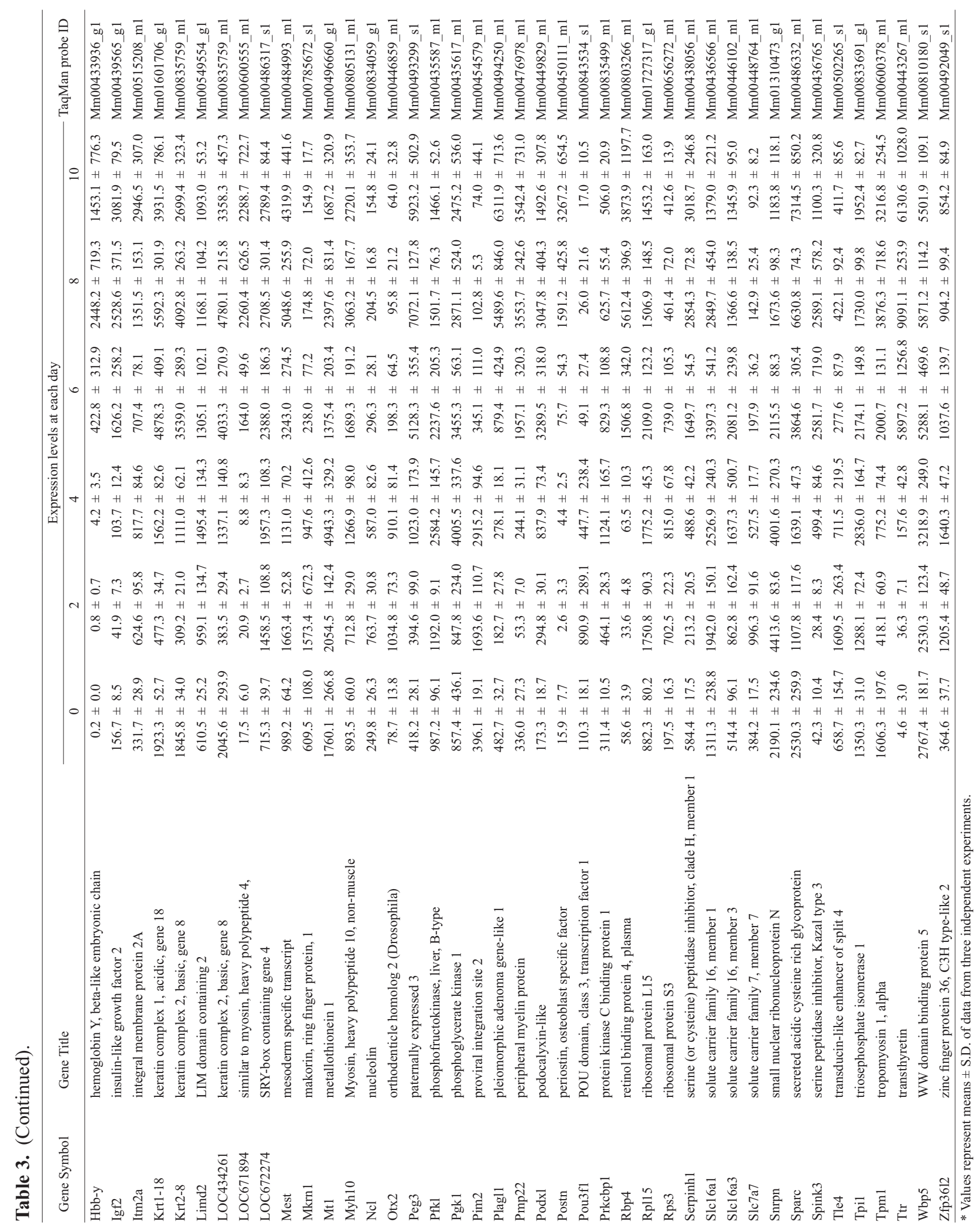

Vol. 36 No. 5 
N. Suzuki et al.

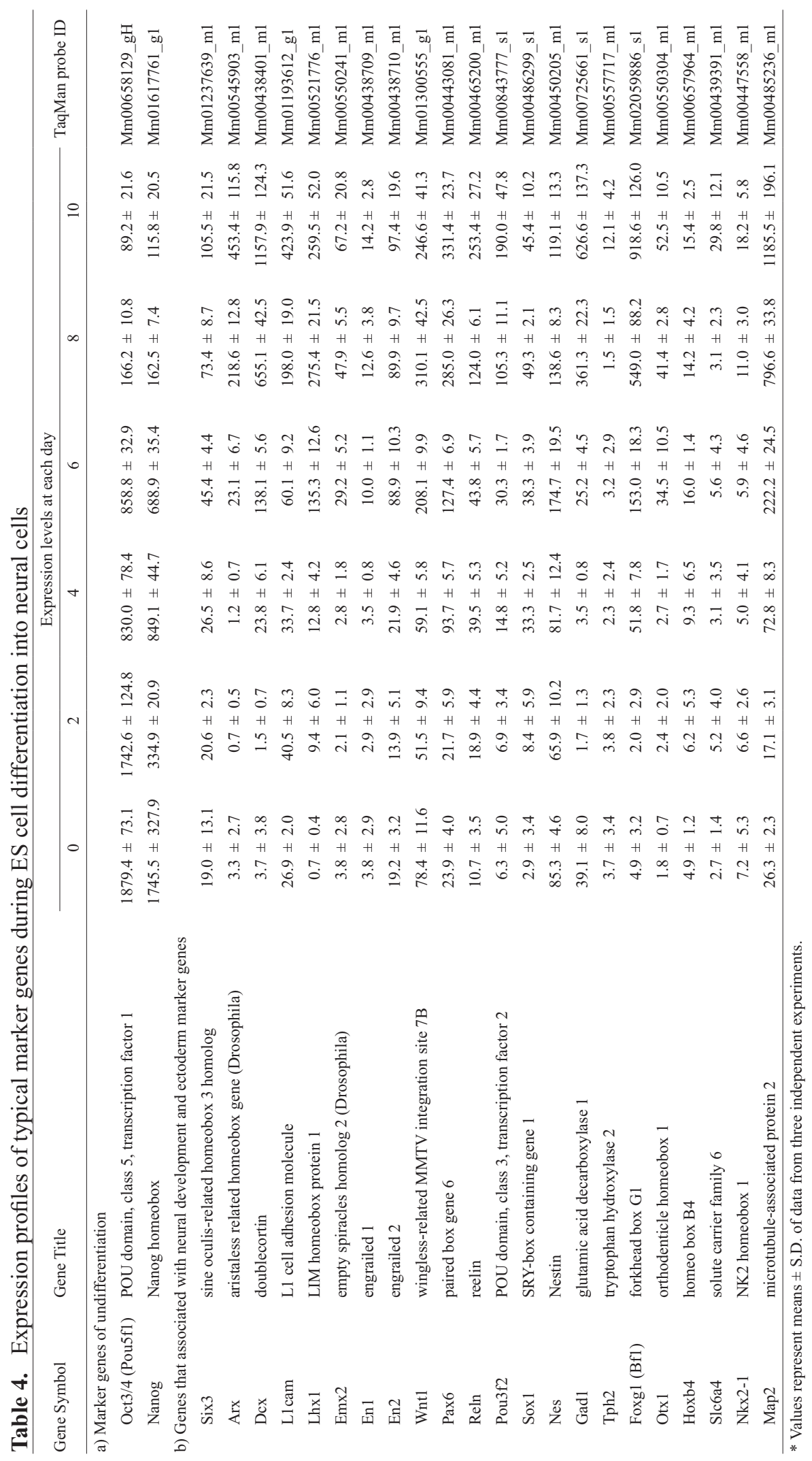

Vol. 36 No. 5 
Genes related to developmental toxicity

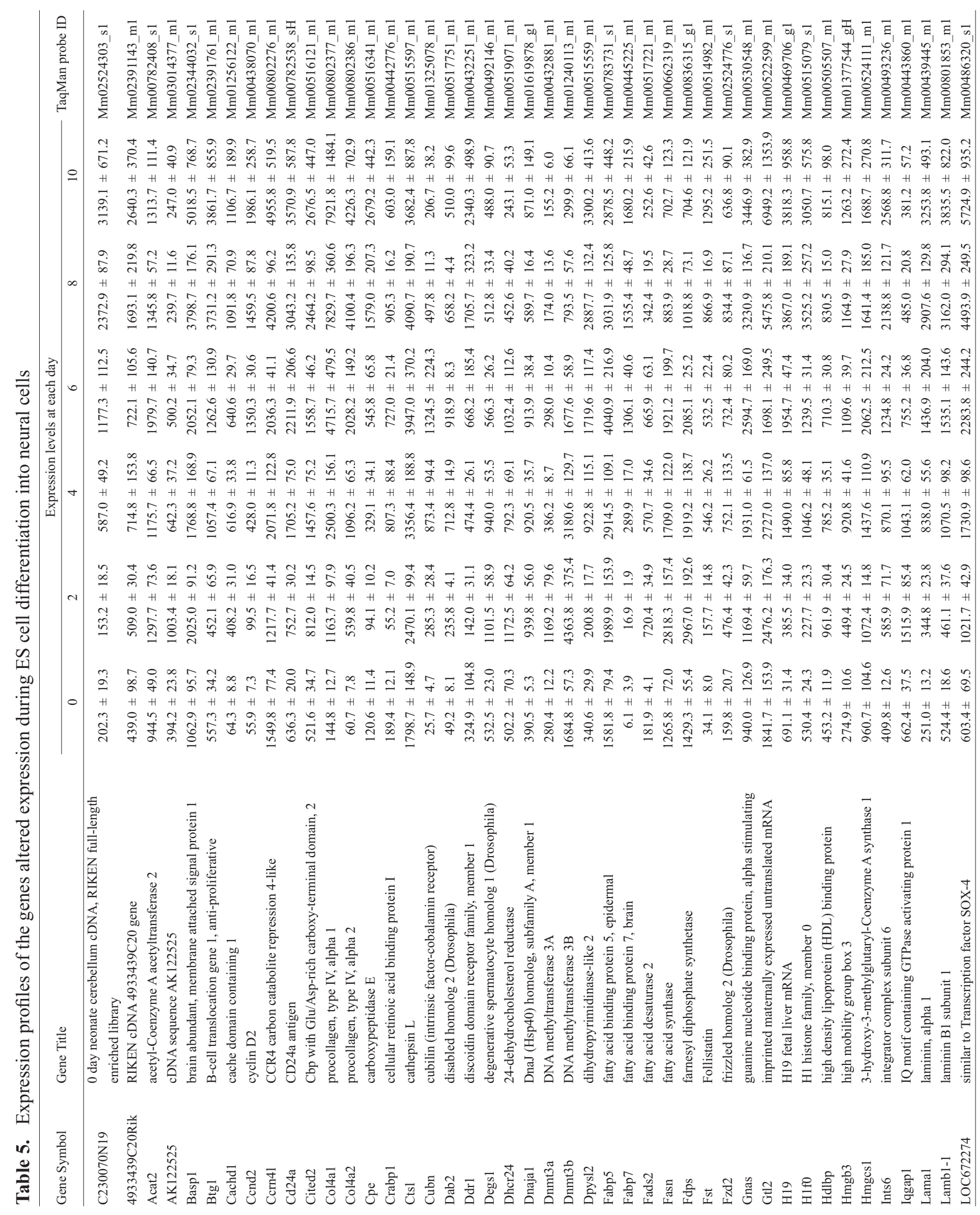

Vol. 36 No. 5 
N. Suzuki et al.

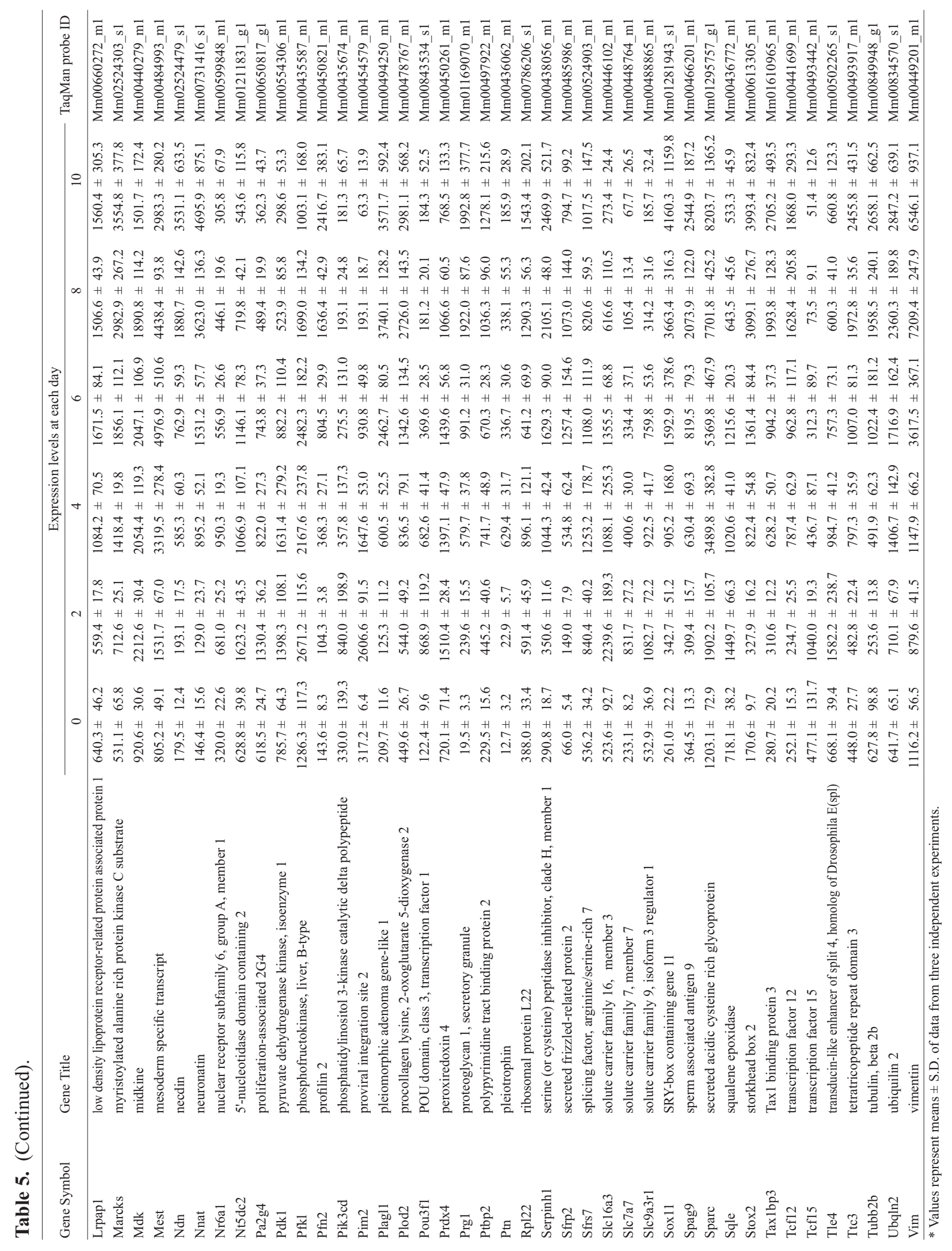

Vol. 36 No. 5 
PBS(-)

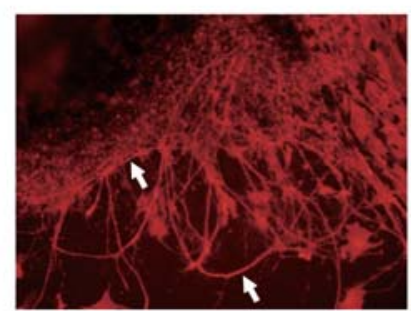

DMSO

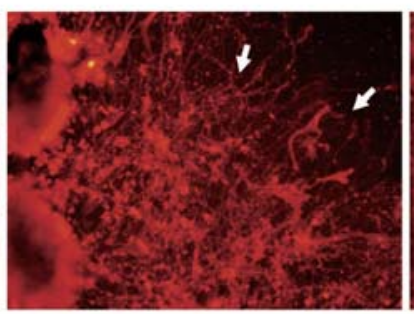

5-Fluorouracil $0.04 \mu \mathrm{g} / \mathrm{ml}$

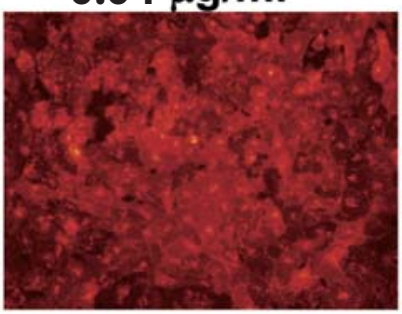

\section{Saccharin sodium} salt hydrate $1000 \mu \mathrm{g} / \mathrm{ml}$

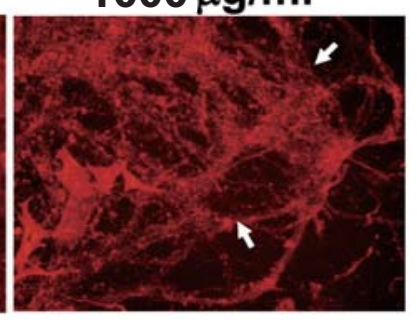

Fig. 1. Confirmation of inhibition of neural differentiation treated with test chemicals. Differentiated cells were visualized by labeling with Vybrant ${ }^{\circledR}$ DiI cell-labeling solution. Each arrowhead represents neural filaments.

acid, isoniazide, $(+)$-camphor and acrylamide) used in the ECVAM international validation study (Brown, 2002; Genschow et al., 2004) were added during ES cell differentiation into myocardiac cells. Chemical dependent changes in expression of candidate genes (Tables 2b, 3 , $4 \mathrm{~b}$ and 5) were then compared between the cells treated with embryotoxicants and non-embryotoxicants.

In the present study, the doses of the test chemicals were set as maximum non-effect concentrations in cytotoxicity assays or minimum concentrations giving 100\% inhibition in differentiation assays (Table 1). In the myocardic cell differentiation, more than $87 \%$ of EBs were contracted spontaneously with solvent control at day 10 , however, no contracting myocardiac cells were observed with embryotoxicants at the concentrations described in Table1 (data not shown). In the case of neuron differentiation, the percentage inhibition of differentiation was calculated by counting the neurofilaments. As shown in Fig. 1, treatment with all embyotoxicants caused 100\% inhibition of neuron differentiation at the doses in Table 1. However, no apparent effects on neuron differentiation were observed with any of the non-embryotoxicant treatments, the doses of non-embryotoxicant being set as the maximum non-effect concentrations in cytotoxicity assays. There were slight differences in the dose levels of part compounds between myocardiac and neural cell differentiation, implying the sensitivity of the differentiated cells against test chemicals.

Comparison between gene expression with embryotoxicants and non-embryotoxicants during ES cell differentiation into myocardiac cells are shown in Table 6. The expression of Hand 1 gene in cells treated with embryotoxicants was strongly reduced in comparison with the vehicle control at day 6 . Significant differences between gene expression with embryotoxicants and non-embryotoxicants were observed in the case of Hand1, Hbb-bh1, Hba-a1, Hba-x, Myl4, My17, Cmya1 and Smyd1. Weak but significant reduction of expression of Pim2, Tbx20, Colla2, Pitx2 and Adam19 was also detected in cells treated with embryotoxicants, but not the non-embryotoxicants. In contrast, there were no apparent effects on expression of Bmp2, Cer1, Gata4, Nkx25, $\alpha$-MHC(Myh6), Mef2a, Mef2c, Cdh2, Tbx5, Nodal, Tpm 2 and T (brachyury) (data not shown). Altered expression of the 13 genes (Hand1, Pim2, Tbx20, Myl4, Myl7, Hbb-bh1, Hba-a1, Col1a2, Hba-x, Cmya1, Pitx2, Smyd1 and Adam1) specifically by embryotoxic chemicals were considered to be correlated with embryotoxicity.

In the case of neural differentiation, expression of 107 genes was examined using quantitative real-time PCR, data for several candidate genes being shown in Table 7 . The expression of Map2 in the cells treated with embryotoxicants was strongly reduced in comparison with vehicle control on day 10, significant differences between gene expression with embryotoxicants and non-embryotoxicants being observed. Similar results were found for Cpe, Marcks, Ptbp2, Sox11, Tubb2b, Vim, Arx, Emx2, Pax6, Basp1, Ddr1, Ndn, Sfrp, Ttc3, Ubqln2, Six3, Dcx, L1cam, Reln, Wnt1 and Nnat.

\section{DISCUSSION}

ES cells derived from the inner cell mass of blastocysts are a self-renewing population, and can be continuously cultured in an undifferentiated state (Evans and Kaufman, 1981; Thomson et al., 1998). Their differentiation mimics the early processes involved in embryonic development, and in the present study we obtained data confirming this 
Table 6. Comparison between marker gene expression with embryotoxicants and non-embryotoxicants during ES cell differentiation into myocardiac cells

\begin{tabular}{|c|c|c|c|}
\hline \multirow[b]{2}{*}{ Gene } & \multirow[b]{2}{*}{ Day } & \multicolumn{2}{|c|}{ Relative expression a } \\
\hline & & Embryotoxicant & $\begin{array}{c}\text { Non- } \\
\text { embryotoxicant }\end{array}$ \\
\hline Pim2 & 4 & $0.20 \pm 0.07$ & $1.68 \pm 0.61 * *$ \\
\hline Hand1 & 6 & $0.04 \pm 0.03$ & $1.11 \pm 0.49 * *$ \\
\hline Hbb-bh1 & 7 & $0.02 \pm 0.01$ & $1.04 \pm 0.74 *$ \\
\hline Hba-a1 & 7 & $0.03 \pm 0.01$ & $1.29 \pm 1.01 *$ \\
\hline Hba-x & 7 & $0.02 \pm 0.03$ & $0.89 \pm 0.67 *$ \\
\hline Myl4 & 8 & $0.03 \pm 0.04$ & $0.49 \pm 0.45 *$ \\
\hline Myl7 & 8 & $0.02 \pm 0.02$ & $0.32 \pm 0.26^{*}$ \\
\hline Cmyal & 8 & $0.02 \pm 0.04$ & $0.57 \pm 0.51 *$ \\
\hline Smyd1 & 8 & $0.04 \pm 0.04$ & $0.55 \pm 0.45 *$ \\
\hline Tbx20 & 9 & $0.26 \pm 0.15$ & $1.65 \pm 0.69 * *$ \\
\hline Pitx2 & 9 & $0.45 \pm 0.20$ & $1.76 \pm 1.14 *$ \\
\hline Adam19 & 10 & $0.48 \pm 0.12$ & $1.10 \pm 0.16 * *$ \\
\hline Col1a2 & 10 & $0.16 \pm 0.11$ & $1.04 \pm 0.65 *$ \\
\hline
\end{tabular}

fact. Thus expression of typical marker genes (Oct3/4 and Nanog) for undifferentiated state decreased gradually during cardiac differentiation, and increase in expression of Myh6 (Ching et al., 2005), typical marker gene for myocardiac cell, was found (Tables $2 \mathrm{a}$ and $\mathrm{b}$ ), suggesting that ES cells differentiated into myocardiac cells. In addition, increase in expression of the well-known mesoderm markers and several genes playing important roles in vertebrate heart formation were evident (Table 2b). For example, increases in expressions of Nodal induced in period cardiac crescent formation ( $\mathrm{Lu}$ and Robertson, 2004), the myocardiac-specific transcription factors, Nkx2-5 (Hiroi et al., 2001) and Mef2C (Lin et al., 1997), and a heart looping mediating factor, Xin (Cmya1) (Wang et al., 1999) were observed. These expression patterns reflected a rough concordance with the gene expression patterns observed during the differentiation of early embryogenesis in vivo (Guan et al., 1999; Rohwedel et al., 2001). This observation suggested that in vitro embryonic stem cell differentiation might replicate many processes that occur during in vivo embryogenesis, therefore might be an appropriate surrogate for the embryo with
Table 7. Comparison between marker gene expression with embryotoxicants and non-embryotoxicants during ES cell differentiation into neural cells

\begin{tabular}{|c|c|c|c|}
\hline \multirow[b]{2}{*}{ Gene } & \multirow[b]{2}{*}{ Day } & \multicolumn{2}{|c|}{ Relative expression a } \\
\hline & & Embryotoxicant & $\begin{array}{c}\text { Non- } \\
\text { embryotoxicant }\end{array}$ \\
\hline Sfrp & 7 & $0.14 \pm 0.17$ & $0.79 \pm 0.33^{* *}$ \\
\hline Wnt1 & 7 & $0.21 \pm 0.36$ & $2.55 \pm 0.84 * *$ \\
\hline Vim & 8 & $0.06 \pm 0.07$ & $0.62 \pm 0.11 * *$ \\
\hline Basp1 & 9 & $0.06 \pm 0.08$ & $0.59 \pm 0.10 * *$ \\
\hline Ddr1 & 9 & $0.06 \pm 0.07$ & $0.58 \pm 0.10 * *$ \\
\hline Marcks & 9 & $0.18 \pm 0.21$ & $1.44 \pm 0.22 * *$ \\
\hline Ptbp2 & 9 & $0.18 \pm 0.21$ & $1.51 \pm 0.31 * *$ \\
\hline Sox11 & 9 & $0.05 \pm 0.06$ & $0.90 \pm 0.39 * *$ \\
\hline Ttc3 & 9 & $0.12 \pm 0.14$ & $0.90 \pm 0.20 * *$ \\
\hline Tubb2b & 9 & $0.10 \pm 0.11$ & $1.33 \pm 0.32 * *$ \\
\hline Ubqln2 & 9 & $0.16 \pm 0.18$ & $0.96 \pm 0.30 * *$ \\
\hline Six 3 & 9 & $0.07 \pm 0.09$ & $0.48 \pm 0.25 * *$ \\
\hline Arx & 9 & $0.05 \pm 0.07$ & $0.65 \pm 0.14 * *$ \\
\hline Dcx & 9 & $0.10 \pm 0.12$ & $1.05 \pm 0.54 * *$ \\
\hline Emx2 & 9 & $0.02 \pm 0.04$ & $0.74 \pm 0.30 * *$ \\
\hline Reln & 9 & $0.05 \pm 0.06$ & $0.79 \pm 0.30 * *$ \\
\hline Map2 & 10 & $0.03 \pm 0.04$ & $0.71 \pm 0.20 * *$ \\
\hline Cpe & 10 & $0.06 \pm 0.07$ & $0.95 \pm 0.28 * *$ \\
\hline $\mathrm{Ndn}$ & 10 & $0.13 \pm 0.16$ & $1.47 \pm 0.28 * *$ \\
\hline L1Cam & 10 & $0.03 \pm 0.03$ & $0.75 \pm 0.34 * *$ \\
\hline Pax6 & 10 & $0.03 \pm 0.04$ & $0.75 \pm 0.22 * *$ \\
\hline Nnat & 10 & $0.07 \pm 0.08$ & $0.75 \pm 0.23 * *$ \\
\hline
\end{tabular}

a: Values represent expression relative to control in the treatment group of six embryotoxants or non-embryotoxicants (mean \pm S.D.). ${ }^{* *}: \mathrm{p}<0.01{ }^{*}: \mathrm{p}<0.05$

respect to developmental toxicity.

The primary aim of the present study was to identifyuseful marker genes for determination of embryotoxicants by transcriptome methods. When chemical dependent changes in expression of the selected genes (107 genes, Tables $2 b$ and 3 ) were compared between ES cells treated with embryotoxic and non-embryotoxic chemicals by a quantitative PCR method, expression of 13 genes (Hand1, Pim2, Tbx20, Myl4, Myl7, Hbb-bh1, Hbaa1, Col1a2, Hba-x, Cmya1, Pitx2, Smyd1 and Adam19) was decreased specifically with the embryotoxic agents. A basic helix-loop-helix transcription factor, Hand1, is 
Genes related to developmental toxicity

known to display dynamic and spatially restricted expression patterns in the developing heart (Cross et al., 1995). Mice that lack Hand1 die on embryonic day 8.5 from placental and extra-embryonic abnormalities (Firulli et al., 1998; Riley et al., 1998). In addition, mice harboring a conditional Hand1 knock out by cardiac-specific expression displayed defects in the left ventricle and endocardial cushions, and exhibited cardiac abnormalities (McFadden et al., 2005). The intercalated disk protein Xin (Cmya1) was originally discovered in chicken striated muscle and implicated in cardiac morphogenesis (Wang et al., 1999). Transcription factors Nkx2-5 and Mef2C activate the Xin gene, and mediate heart looping. The hearts of Xin $\alpha$-null mice are hypertrophied and exhibited fibrosis, indicative of cardiomyopathy (Gustafson-Wagner et al., 2007). Furthermore, mice lacking functional Adam19 exhibit severe defects in cardiac morphogenesis including ventricular septal abnormalities (Komatsu et al., 2007). The Pitx2 transcription factor, activated solely in the left side of the lateral plate mesoderm, is also critical for proper heart looping, and it might regulate the expression of proteins such as the extracellular matrix protein to regulate the physical tension of the heart tissues on the different sides (Tsuda et al., 1996). Moreover, the other genes were all known to be indispensable in heart development (Stennard et al., 2003; Cohen-Haguenauer et al., 1989; Maves et al., 2009; Muscat et al., 1988; Gottlieb et al., 2002), implying that the 13 genes identified in the present study are intimately involved in embryotoxicity of chemicals. Changes in expression of key genes (Oct$3 / 4$, Brachury, Nkx2.5 and $\alpha-\mathrm{MHC}$ ) involved in cardiomyocyte development were reported during ES cell differentiation into cardiomyocytes with retinoic acid and $\mathrm{LiCl}$ (Pelizzer et al., 2004), decreases in gene expression of $\mathrm{Nkx} 2.5$ and $\alpha$-MHC being also found. In the present study, decreases in $\mathrm{Nkx} 2.5$ and $\alpha$-MHC expression were clearly observed after treatment with retinoic acid (data not shown), but the changes in both genes were not specific to the 6 embryotoxicants used, so that they can not be selected as marker genes for embryotoxicity. Recently, gene expression during early stages of ES cell differentiation into cardiomyocytes were analyzed with and without exposure of embryotoxicants (monobutyl phthalate and 6-aminonicotinamide) using DNA microarrays, significant deviation of cultures of altered genes from the unexposed and embryotoxicant-exposed cells being reported. However no genes altered with the embryotoxicants were specified (van Dartel et al., 2010a). Then a set of 26 genes altered in ES cells exposed with 5 embryotoxicants (all-trans-retinoic acid, methoxyacetic acid, valproic acid, monobutyl phthalate and 5-fluorouracil) was reported by the same group (van Dartel et al., 2010b). The report was the first identification of embryotoxicantrelated genes by global expression analysis during early stages of ES cell differentiation into cardiomyocytes. In the present study we identified for the first time 13 genes with altered expression specific to treatment with 6 embryotoxicants (5-fluorouracil, hydroxyurea, 6-aminonicotinamide, 5-bromo-2'-deoxyuridine, methotrexate and all-trans-retinoic acid) on the basis of gene expression of ES cells differentiation into cardiomyocytes in comparison with 6 non-embryotoxicants (saccharin sodium salt hydrate, ascorbic acid, isoniazide, D-(+)-camphor, acrylamide and penicillin $G$ ). No genes identical with the 26 genes were found, suggesting that differences were due to the differentiation stage of ES cells or test chemicals used in the present study. The new identified genes are altered specifically by embryotoxicants, therefore, they are more informative and may help to improve in vitro reproductive toxicity methods.

Global changes in the gene expression during ES cell differentiation into neural cells were also analyzed by DNA microarray. Since the cerebral cortex sustains damage in many cases of brain malformation, a differentiation method inducing cerebral cortex neurons efficiently was selected in the present study (Watanabe et al., 2005). Change in expression of typical undifferentiated marker genes (Oct3/4 and Nanog) decreased gradually during neural differentiation. In addition, increased expression of Map2 and Bf1, typical marker genes for neural cells, was found. When chemical dependent changes in expression of up-regulated genes (107 genes, Tables 4b and 5) were compared between ES cells treated with embryotoxic and non-embryotoxic agents by a quantitative PCR method, decreases in gene expression of 22 genes (Map2, Cpe, Marcks, Ptbp2, Sox11, Tubb2b, Vim, Arx, Emx2, Pax6, Basp1, Ddr1, Ndn, Sfrp, Ttc3, Ubqln2, Six3, Dcx, L1cam, Reln, Wnt1 and Nnat) were found specifically with embryotoxic chemicals. Map2 is a typical neural marker gene which is related to a microtubule associated complex essential for neurogenesis. Mutation of the reeler gene (Reln) is known to disrupt neuronal migration in several brain regions and give rise to functional deficits such as ataxic gait and trembling in the reeler mutant mouse (Yip et al., 2000). Necdin (Ndn), a member of the MAGE (melanoma antigen) protein family, is expressed predominantly in terminally differentiated neurons. It is maternally imprinted and expressed only from the paternal allele, a deficiency of which was implicated in the pathogenesis of the neurodevelopment disorder PraderWilli syndrome (Jay et al., 1997). Moreover, the other genes were known to be indispensable in the formation of 
the brain development (Joseph et al., 1994; Pekny et al., 1999; Wu et al., 1999; Bhatt et al., 2000; Frey et al., 2000; Mallamaci et al., 2000; Uwanogho et al., 1995; Brault et al., 2001; Grove, 2002; Kitamura et al., 2002; Lagutin et al., 2003; Duparc et al., 2006; Kappeler et al., 2006; Berto et al., 2007; Resnick et al., 2008; Woronowicz et al., 2008; Jaglin et al., 2009; Weimer et al., 2009; Nakamura et al., 2010). These results suggested that selected 22 genes were related to embryotoxicity, and might be useful for prediction purposes. Several studies have reported on gene expression of major neural-specific genes, such as Nestin, Synaptophysin, NFH, GFAP, Oligo2 and DM20 analyzed for estimation of the embryonic effects of carbamazepine and fluoxetine during ES cell differentiation into neurons (Murabe et al., 2007; Kusakawa et al., 2008). In the present study, although chemical dependent changes in expression of Nestin were compared between embryotoxicant and non-embryotoxicant-treated groups, no embryotoxicant-specific alterations in Nestin expression were observed (data not shown). Although the reasons are not yet clearly understood, it seems to Nestin may not be a useful marker gene for detection of embryotoxicity of chemicals.

The EST was developed in 1997, and was one of the most useful tests for developmental toxicity using mouse ES cells. However, various problems have been pointed out and it has not been generally accepted in test guidelines. One major weakness is its reliance on a morphological endpoint (contracting myocardiac cells) and the need for experienced personnel ensuring reliable assessment. In order to solve this problem, various improvements have been introduced (Marx-Stoelting et al., 2009). During the last decade the reported cases of usage for molecular markers instead of morphological endpoints have increased. The number of the selected marker genes is presently too limited to identify the best molecular endpoint for classification of embryotoxicity. However, identification of potential chemical effects on myocardic, osteogenic, chondrogenic and neural differentiation by quantitative PCR methods were reported using a myosin heavy chain ( $\alpha$-MHC/Myh6), Neurofilament, Osteocalcin and Aggrecan, respectively (zur Nieden et al., 2004). Recently, new molecular endpoints of differentiation have been introduced with a flow cytometry method (FACSEST) by cardiac myosin using antibodies against sarcomeric $\alpha$-MHC (Seiler et al., 2004; Buesen et al., 2009). In the present study, although chemical dependent changes in gene expression of $\alpha$-MHC were compared between embryotoxicant and non-embryotoxicant- treated ES cells by a quantitative PCR method, no embryotoxicant-specific changes in expression of $\alpha-\mathrm{MHC}$ were found (data not shown). In the present study, we identified myosin light chains such as Myl4 and Myl7 as the specific markers for embryotoxicants (Table 6). Cardiac muscle thick filaments are primarily composed of cardiac myosin which assembles into hexamers comprised of 2 heavy chains and 2 pairs of each light chain isoform (essential light chain and regulatory light chain) (Craig and Woodhead, 2006). These results imply that decreases in Myl4 or Myl7 gene expression caused reduction of cardiac myosin protein levels detected by antibodies against sarcomeric $\alpha$-MHC. In the present study we could successfully identify several marker genes related to embryotoxicity by transcriptome methods. Although, further studies are required to confirm our identified genes, monitoring of the identified marker genes might be useful as endpoints in an ES cell based animal-free alternative test for embryotoxicity.

One other problem is that the assay period of 10 days of EST was rather long for screening purposes for drugs and chemicals. Reduction in the assay duration is advantageous in terms of simplicity, economy, and reproducibility. A recent study reported that quantitative FACS analyses of $\alpha$-MHC marker proteins could be performed at day 7 and the assay period was thus reduced (Buesen et al., 2009). The obtained marker genes in the present study were expressed at days 4 to 10 after induction of differentiation into myocardiac or neural cells. Use of our identified genes can be considered of particular value for the endpoint because detectable expression levels were observed at days 4-6. Quantitative determination of their expression might be useful for improvement of EST. One of the most promising methods for detection of the marker genes is use of stable transgenic ES cells for detection with reporter genes. Employment of the GFP as a reporter gene connected to a tissue-specific promoter was reported for easy identification of myocardial cells derived from ES cells (Kolossov et al., 1998). However, stable transgenic ES cells for detection of marker gene expression by luciferase reporter genes would be useful for high-throughput screening, and we have establishing several examples for the propose of screening or prediction of embryotoxicity of chemicals in the future. In addition, humanization of in vitro developmental test methods is clearly required, as species differences in developmental toxicity are known for various chemicals such as thalidomide. To satisfy test requirements, use of human ES (Adler et al., 2008) or iPS (Takahashi and Yamanaka, 2006; Takahashi et al., 2007) cells is very promising for the near future. The present findings provide an experimental model suitable for studies of embryotoxicity, although further investigations are now required to clarify the exact relationships between genes identified in the present study and embryotoxicity. 
Genes related to developmental toxicity

\section{ACKNOWLEDGMENT}

We would like to thank Norihisa Yamashita and Akane Muroi for grateful technical support. This study was supported by NEDO (New Energy and Industrial Technology Development Organization).

\section{REFERENCES}

Adler, S., Pellizzer, C., Hareng, L., Hartung, T. and Bremer, S. (2008): First steps in establishing a developmental toxicity test method based on human embryonic stem cells. Toxicol. In Vitro, 22, 200-211.

Berto, G., Camera, P., Fusco, C., Imarisio, S., Ambrogio, C., Chiarle, R., Silengo, L. and Di Cunto, F. (2007): The Down syndrome critical region protein TTC3 inhibits neuronal differentiation via RhoA and Citron kinase. J. Cell Sci., 120, 1859-1867.

Bhatt, R.S., Tomoda, T., Fang, Y. and Hatten, M.E. (2000): Discoidin domain receptor 1 functions in axon extension of cerebellar granule neurons. Genes Dev., 14, 2216-2228.

Brault, V., Moore, R., Kutsch, S., Ishibashi, M., Rowitch, D.H., McMahon, A.P., Sommer, L., Boussadia, O. and Kemler, R. (2001): Inactivation of the beta-catenin gene by Wnt1-Cre-mediated deletion results in dramatic brain malformation and failure of craniofacial development. Development, 128, 1253-1264.

Bremer, S. and Hartung T. (2004): The use of embryonic stem cells for regulatory developmental toxicity testing in vitro--the current status of test development. Curr. Pharm. Des., 10, 2733-2747.

Brown, N.A. (2002): Selection of test chemicals for the ECVAM international validation study on in vitro embryotoxicity tests. European Centre for the Validation of Alternative Methods. Altern. Lab. Anim., 30, 177-198

Buesen, R., Genschow, E., Slawik, B., Visan, A., Spielmann, H., Luch, A. and Seiler, A. (2009) Embryonic stem cell test remastered: comparison between the validated EST and the new molecular FACS-EST for assessing developmental toxicity in vitro. Toxicol. Sci., 108, 389-400.

Ching, Y.H., Ghosh, T.K., Cross, S.J., Packham, E.A., Honeyman, L., Loughna, S., Robinson, T.E., Dearlove, A.M., Ribas, G., Bonser, A.J., Thomas, N.R., Scotter, A.J., Caves, L.S., Tyrrell, G.P., Newbury-Ecob, R.A., Munnich, A., Bonnet, D. and Brook, J.D. (2005): Mutation in myosin heavy chain 6 causes atrial septal defect. Nat. Genet., 37, 423-428.

Cohen-Haguenauer, O., Barton, P.J., Van Cong, N., Cohen, A., Masset, M., Buckingham, M. and Frézal, J. (1989): Chromosomal assignment of two myosin alkali light-chain genes encoding the ventricular/slow skeletal muscle isoform and the atrial/fetal muscle isoform (MYL3, MYL4). Hum. Genet., 81, 278-282.

Craig, R. and Woodhead, J.L. (2006): Structure and function of myosin filaments. Curr. Opin. Struct. Biol., 16, 204-212.

Cross, J.C., Flannery, M.L., Blanar, M.A., Steingrimsson, E., Jenkins, N.A., Copeland, N.G., Rutter, W.J. and Werb, Z. (1995): Hxt encodes a basic helix-loop-helix transcription factor that regulates trophoblast cell development. Development, 121, 2513-2523.

Davila, J.C., Cezar, G.G., Thiede, M., Strom, S., Miki, T. and Trosko, J. (2004): Use and application of stem cells in toxicology. Toxicol. Sci., 79, 214-23.

Duparc, R.H., Boutemmine, D., Champagne, M.P., Tétreault, N. and Bernier, G. (2006): Pax6 is required for delta-catenin/neurojugin expression during retinal, cerebellar and cortical development in mice. Dev. Biol., 300, 647-655.

Evans, M.J. and Kaufman, M.H. (1981): Establishment in culture of pluripotential cells from mouse embryos. Nature, 292, 154-156.

Firulli, A.B., McFadden, D.G., Lin, Q., Srivastava, D. and Olson, E.N. (1998): Heart and extra-embryonic mesodermal defects in mouse embryos lacking the bHLH transcription factor Hand1. Nat. Genet., 18, 266-270.

Flint, O.P. and Orton, T.C. (1984): An in vitro assay for teratogens with cultures of rat embryo midbrain and limb bud cells. Toxicol. Appl. Pharmacol., 76, 383-395.

Frey, D., Laux, T., Xu, L., Schneider, C. and Caroni, P. (2000): Shared and unique roles of CAP23 and GAP43 in actin regulation, neurite outgrowth, and anatomical plasticity. J. Cell Biol., 149, 1443-1454.

Genschow, E., Spielmann, H., Scholz, G., Pohl, I., Seiler, A., Clemann, N., Bremer, S. and Becker, K. (2004): Validation of the embryonic stem cell test in the international ECVAM validation study on three in vitro embryotoxicity tests. Altern. Lab. Anim., 32, 209-244.

Gottlieb, P.D., Pierce, S.A., Sims, R.J., Yamagishi, H., Weihe, E.K., Harriss, J.V., Maika, S.D., Kuziel, W.A., King, H.L., Olson, E.N., Nakagawa, O. and Srivastava, D. (2002): Bop encodes a muscle-restricted protein containing MYND and SET domains and is essential for cardiac differentiation and morphogenesis. Nat. Gent., 31, 25-32.

Grove, E. (2002): The telencephalon saved by TLC. Neuron, 35, 215-217.

Guan, K., Rohwedel, J. and Wobus, A.M. (1999): Embryonic stem cell differentiation models: cardiogenesis, myogenesis, neurogenesis, epithelial and vascular smooth muscle cell differentiation in vitro. Cytotechnology, 30, 211-226.

Gustafson-Wagner, E.A., Sinn, H.W., Chen, Y.L., Wang, D.Z., Reiter, R.S., Lin, J.L., Yang, B., Williamson, R.A., Chen, J., Lin, C.I. and Lin, J.J. (2007): Loss of mXin alpha, an intercalated disk protein, results in cardiac hypertrophy and cardiomyopathy with conduction defects. Am. J. Physiol. Heart Circ. Physiol., 293, 2680-2692.

Hiroi, Y., Kudoh, S., Monzen, K., Ikeda, Y., Yazaki, Y., Nagai, R. and Komuro, I. (2001): Tbx5 associates with Nkx2-5 and synergistically promotes cardiomyocyte differentiation. Nat. Genet. 28, 276-280.

Jaglin, X.H., Poirier, K., Saillour, Y., Buhler, E., Tian, G., BahiBuisson, N., Fallet-Bianco, C., Phan-Dinh-Tuy, F., Kong, X.P., Bomont, P., Castelnau-Ptakhine, L., Odent, S., Loget, P., Kossorotoff, M., Snoeck, I., Plessis, G., Parent, P., Beldjord, C., Cardoso, C., Represa, A., Flint, J., Keays, D.A., Cowan, N.J. and Chelly, J. (2009): Mutations in the beta-tubulin gene TUBB2B result in asymmetrical polymicrogyria. Nat. Genet, 41, 746-752.

Jay, P., Rougeulle, C., Massacrier, A., Moncla, A., Mattei, M.G., Malzac, P., Roëckel, N., Taviaux, S., Lefranc, J.L., Cau, P., Berta, P., Lalande, M. and Muscatelli, F. (1997): The human necdin gene, NDN, is maternally imprinted and located in the Prader-Willi syndrome chromosomal region. Nat. Genet, 17, $357-$ 361.

Joseph, R., Dou, D. and Tsang, W. (1994): Molecular cloning of a novel mRNA (neuronatin) that is highly expressed in neonatal mammalian brain. Biochem. Biophys. Res. Commun., 201, 1227-1234.

Kappeler, C., Saillour, Y., Baudoin, J.P., Tuy, F.P., Alvarez, C., Houbron, C., Gaspar, P., Hamard, G., Chelly, J., Métin, C. and Francis, F. (2006): Branching and nucleokinesis defects in 
N. Suzuki et al.

migrating interneurons derived from doublecortin knockout mice. Hum. Mol. Genet., 15, 1387-1400.

Kawaguchi, A., Miyata, T., Sawamoto, K., Takashita, N., Murayama, A., Akamatsu, W., Ogawa, M., Okabe, M., Tano, Y., Goldman, S.A. and Okano, H. (2001): Nestin-EGFP transgenic mice: visualization of the self-renewal and multipotency of CNS stem cells. Mol. Cell. Neurosci., 17, 259-273.

Kawasaki, H., Mizuseki, K., Nishikawa, S., Kaneko, S., Kuwana, Y., Nakanishi, S., Nishikawa, S.I. and Sasai, Y. (2000): Induction of midbrain dopaminergic neurons from ES cells by stromal cell-derived inducing activity. Neuron, 28, 31-40.

Kitamura, K., Yanazawa, M., Sugiyama, N., Miura, H., IizukaKogo, A., Kusaka, M., Omichi, K., Suzuki, R., Kato-Fukui, Y., Kamiirisa, K., Matsuo, M., Kamijo, S., Kasahara, M., Yoshioka, H., Ogata, T., Fukuda, T., Kondo, I., Kato, M., Dobyns, W.B., Yokoyama, M. and Morohashi, K. (2002): Mutation of ARX causes abnormal development of forebrain and testes in mice and X-linked lissencephaly with abnormal genitalia in humans. Nat. Genet., 32, 359-369.

Kolossov, E., Fleischmann, B.K., Liu, Q., Bloch, W., ViatchenkoKarpinski, S., Manzke, O., Ji, G.J., Bohlen, H., Addicks, K. and Hescheler, J. (1998): Functional characteristics of ES cellderived cardiac precursor cells identified by tissue-specific expression of the green fluorescent protein. J. Cell Biol., 143, 2045-2056.

Komatsu, K., Wakatsuki, S., Yamada, S., Yamamura, K., Miyazaki, J. and Sehara-Fujisawa A. (2007): Meltrin beta expressed in cardiac neural crest cells is required for ventricular septum formation of the heart. Dev. Biol., 303, 82-92.

Kusakawa, S., Yamauchi, J., Miyamoto, Y., Sanbe, A. and Tanoue, A. (2008): Estimation of embryotoxic effect of fluoxetine using embryonic stem cell differentiation system. Life Sci., 83, 871877.

Lagutin, O.V., Zhu, C.C., Kobayashi, D., Topczewski, J., Shimamura, K., Puelles, L., Russell, H.R., McKinnon, P.J., Solnica-Krezel, L. and Oliver, G. (2003):. Six3 repression of Wnt signaling in the anterior neuroectoderm is essential for vertebrate forebrain development. Genes Dev., 17, 368-379.

Lin, Q., Schwarz, J., Bucana, C. and Olson, E.N. (1997): Control of mouse cardiac morphogenesis and myogenesis by transcription factor MEF2C. Science, 276, 1404-1407.

Lu, C.C. and Robertson, E.J. (2004): Multiple roles for Nodal in the epiblast of the mouse embryo in the establishment of anteriorposterior patterning. Dev. Biol., 273, 149-159.

Mallamaci, A., Mercurio, S., Muzio, L., Cecchi, C., Pardini, C.L., Gruss, P., Boncinelli, E. (2000): The lack of Emx2 causes impairment of Reelin signaling and defects of neuronal migration in the developing cerebral cortex. J. Neurosci., 20, 1109-1118.

Marx-Stoelting, P., Adriaens, E., Ahr, H.J., Bremer, S., Garthoff, B., Gelbke, H.P., Piersma, A., Pellizzer, C., Reuter, U., Rogiers, V., Schenk, B., Schwengberg, S., Seiler, A., Spielmann, H., Steemans, M., Stedman, D.B., Vanparys, P., Vericat, J.A., Verwei, M., van der Water, F., Weimer, M. and Schwarz, M. (2009): A review of the implementation of the embryonic stem cell test (EST). The report and recommendations of an ECVAM ReProTect Workshop. Altern. Lab. Anim., 37, 313-328.

Maves, L., Tyler, A., Moens, C.B. and Tapscott, S.J. (2009): Pbx acts with Hand 2 in early myocardial differentiation. Dev. Biol., 333, 409-418.

McFadden, D.G., Barbosa, A.C., Richardson, J.A., Schneider, M.D., Srivastava, D. and Olson, E.N. (2005): The Hand1 and Hand2 transcription factors regulate expansion of the embryonic cardi- ac ventricles in a gene dosage-dependent manner. Development, 132, 189-201.

Murabe, M., Yamauchi, J., Fujiwara, Y., Miyamoto, Y., Hiroyama, M., Sanbe, A. and Tanoue, A. (2007): Estimation of the embryotoxic effect of CBZ using an ES cell differentiation system. Biochem. Biophys. Res. Commun., 356, 739-744.

Muscat, G.E., Gustafson, T.A. and Kedes, L. (1988): A common factor regulates skeletal and cardiac alpha-actin gene transcription in muscle. Mol. Cell Biol., 8, 4120-4133.

Nakamura, Y., Lee, S., Haddox, C.L., Weaver, E.J,, Lemmon, V.P. (2010): Role of the cytoplasmic domain of the L1 cell adhesion molecule in brain development. J. Comp. Neurol., 518, 11131132.

Pekny, M., Johansson, C.B., Eliasson, C., Stakeberg, J., Wallén, A., Perlmann, T., Lendahl, U., Betsholtz, C., Berthold, C.H. and Frisén, J. (1999): Abnormal reaction to central nervous system injury in mice lacking glial fibrillary acidic protein and vimentin. J. Cell Biol., 145, 503-514.

Pellizzer, C., Adler, S., Corvi, R., Hartung, T. and Bremer, S. (2004): Monitoring of teratogenic effects in vitro by analysing a selected gene expression pattern. Toxicol. In Vitro, 18, 325-335.

Resnick, M., Segall, A., G, G.R., Lupowitz, Z. and Zisapel, N. (2008): Alternative splicing of neurexins: a role for neuronal polypyrimidine tract binding protein. Neurosci. Lett., 439, 235240

Riley, P., Anson-Cartwright, L. and Cross, J.C. (1998): The Hand 1 bHLH transcription factor is essential for placentation and cardiac morphogenesis. Nat. Genet., 18, 271-275.

Rohwedel, J., Guan, K., Hegert, C. and Wobus, A.M. (2001): Embryonic stem cells as an in vitro model for mutagenicity, cytotoxicity and embryotoxicity studies: present state and future prospects. Toxicol. In Vitro, 15, 741-753.

Schmid, B.P., Kao, J. and Goulding, E. (1985): Evidence for reopening of the cranial neural tube in mouse embryos treated with cadmium chloride. Experientia, 41, 271-272.

Scholz, G., Pohl, I., Genschow, E., Klemm, M. and Spielmann, H. (1999): Embryotoxicity screening using embryonic stem cells in vitro: correlation to in vivo teratogenicity. Cells Tissues Organs, $165,203-211$

Seiler, A., Buesen, R., Hayess, K., Schlechter, K., Visan, A., Genschow, E., Slawik, B. and Spielmann, H. (2006): Current status of the embryonic stem cell test: the use of recent advances in the field of stem cell technology and gene expression analysis. ALTEX, 23, 393-399.

Seiler, A., Visan, A., Buesen, R., Genschow, E. and Spielmann, H. (2004): Improvement of an in vitro stem cell assay for developmental toxicity: the use of molecular endpoints in the embryonic stem cell test. Reprod. Toxicol., 18, 231-240.

Smith, M.K., Kimmel, G.L., Kochhar, D.M., Shepard, T.H., Spielberg, S.P. and Wilson, J.G. (1983): A selection of candidate compounds for in vitro teratogenesis test validation. Teratog Carcinog Mutagen., 3, 461-480.

Spielmann, H., Pohl, I., Doering, B., Liebsch, M. and Moldenhauer, F. (1997): The embryonic stem cell test, an in vitro embryotoxicity test using two permanent mouse cell lines: $3 \mathrm{~T} 3$ fibroblasts and embryonic stem cells. In vitro Toxicol., 10, 119-127.

Spielmann, H. (1998): Reproduction and development. Environ. Health Perspect., 106, Suppl 2, 571-576.

Stennard, F.A., Costa, M.W., Elliott, D.A., Rankin, S., Haast, S.J., Lai, D., McDonald, L.P., Niederreither, K., Dolle, P., Bruneau, B.G., Zorn, A.M. and Harvey, R.P. (2003): Cardiac T-box factor Tbx20 directly interacts with Nkx2-5, GATA4, and GATA5 
Genes related to developmental toxicity

in regulation of gene expression in the developing heart. Dev. Biol., 262, 206-224.

Takahashi, K., Tanabe, K., Ohnuki, M., Narita, M., Ichisaka, T., Tomoda, K. and Yamanaka, S. (2007): Induction of pluripotent stem cells from adult human fibroblasts by defined factors. Cell, 131, 861-872.

Takahashi, K. and Yamanaka, S. (2006): Induction of pluripotent stem cells from mouse embryonic and adult fibroblast cultures by defined factors. Cell, 126, 663-676.

Thomson, J.A., Itskovitz-Eldor, J., Shapiro, S.S., Waknitz, M.A., Swiergiel, J.J., Marshall, V.S. and Jones, J.M. (1998): Embryonic stem cell lines derived from human blastocysts. Science, 282, 1145-1147.

Tsuda, T., Philp, N., Zile, M.H. and Linask, K.K. (1996): Left-right asymmetric localization of flectin in the extracellular matrix during heart looping. Dev. Biol., 173, 39-50.

Uwanogho, D., Rex, M., Cartwright, E.J., Pearl, G., Healy, C., Scotting, P.J. and Sharpe, P.T. (1995): Embryonic expression of the chicken Sox2, Sox3 and Sox11 genes suggests an interactive role in neuronal development. Mech Dev., 49, 23-36.

van Dartel, D.A., Pennings, J.L., van Schooten, F.J. and Piersma, A.H. (2010a): Transcriptomics-based identification of developmental toxicants through their interference with cardiomyocyte differentiation of embryonic stem cells. Toxicol. Appl. Pharmacol., 243, 420-428.

van Dartel, D.A., Pennings, J.L., de la Fonteyne, L.J., van Herwijnen, M.H., van Delft, J.H., van Schooten, F.J. and Piersma, A.H. (2010b): Monitoring developmental toxicity in the embryonic stem cell test using differential gene expression of differentiation-related genes. Toxicol. Sci., 116, 130-139.
Wang, D.Z., Reiter, R.S., Lin, J.L., Wang, Q., Williams, H.S., Krob, S.L., Schultheiss, T.M., Evans, S. and Lin, J.J. (1999): Requirement of a novel gene, Xin, in cardiac morphogenesis. Development, 126, 1281-1294.

Watanabe, K., Kamiya, D., Nishiyama, A., Katayama, T., Nozaki, S., Kawasaki, H., Watanabe, Y., Mizuseki, K. and Sasai, Y. (2005): Directed differentiation of telencephalic precursors from embryonic stem cells. Nature Neurosci., 8, 288-296.

Weimer, J.M., Yokota, Y., Stanco, A., Stumpo, D.J., Blackshear, P.J. and Anton, E.S. (2009): MARCKS modulates radial progenitor placement, proliferation and organization in the developing cerebral cortex. Development, 136, 2965-2975.

Woronowicz, A., Koshimizu, H., Chang, S.Y., Cawley, N.X., Hill, J.M., Rodriguiz, R.M., Abebe, D., Dorfman, C., Senatorov, V., Zhou, A., Xiong, Z.G., Wetsel, W.C. and Loh, Y.P. (2008): Absence of carboxypeptidase E leads to adult hippocampal neuronal degeneration and memory deficits. Hippocampus, 18, 1051-1063.

Wu, A.L., Wang, J., Zheleznyak, A. and Brown, E.J. (1999): Ubiquitin-related proteins regulate interaction of vimentin intermediate filaments with the plasma membrane. Molecular Cell, 4, 619625.

Yip, J.W., Yip, Y.P., Nakajima, K. and Capriotti, C. (2000): Reelin controls position of autonomic neurons in the spinal cord. Proc. Natl. Acad. Sci. USA, 97, 8612-8616.

zur Nieden, N.I., Kempka, G. and Ahr, H.J. (2004): Molecular multiple endpoint embryonic stem cell test--a possible approach to test for the teratogenic potential of compounds. Toxicol. Appl. Pharmacol., 194, 257-269. 